lenses were milky-looking, and there were very definite sectors of opacity running in from the periphery, as well as minute darlo points towards the centre. I am sure I was not mistaking opacitiesp in the vitreous for opacities in the lens. I gave rather a bad prognosis to her doctor, but hoped they would clear up, as I knewe opacities in the lenses did clear away sometimes. I saw her 12 months later, and much to my surprise and pleasure her eyes to all appearances were quite well. She had had no treatment exceptw atropin and the use of dark glasses. Certain remedies had beeno advised, but the patient always declined to take medicines. I have again seen her just recently, and she again has a mild attack of irido-choroiditis in the left eye.

I have once seen a mature senile cataract in a man of 76 years? clear up entirely. This was in a patient I saw for over 20 years, and-

- is one of those very exceptional cases we sometimes come across.

STOCKTON-ON-TEES,

November, 1924.
Yours faithfully,

G. Victor Miller.

\title{
CLASSIFICATION OF DISEASES OF THE CHOROID
}

To the Editor of THE British Journal OF Ophthalmologio

DEAR SIR,-Mr. Batten's criticism of my paper and defence of his own position appears to me to be mainly concerned with draw ing distinctions between the clinician and the pathologist, a poine which I have never made in my paper; indeed I think a lesspartial reader would have interpreted my meaning in exactly the opposite sense.

But in order to support his own view, he has fallen into the grave error, quite unintentionally I feel sure, of misquoting me in at least one place, while in others he has interpreted my remarks. in such a way as to place me in a false position, and from this standpoint has attacked my general conclusions.

In the first place he pays me the high compliment of including me amongst the pathologists, a claim which I have never made for myself. I can only recall one very small contribution to the pathology of the eye that I have ever made and which is of notin much importance, and it would be the height of bad taste to alluden to the brilliant advances in pathological knowledge in the lasto 20 years, if I had had any hand in these advances myself; ando yet Mr. Batten assumes that I have taken up this position.

Again he quotes me as stating that a classification of diseases ${ }^{?}$ of the choroid based on ophthalmoscopic examination is a relic of the past, and proceeds to accuse me of ingratitude, and leavesक it to be assumed that I attach relatively little importance to the use of the ophthalmoscope. What I actually said was, that $\frac{0}{\sigma}$ 
"Classification ... . based on the picture displayed to ophthalmoscopic examination-surely a relic of the past-etc.," which is a very different thing. The sentence he puts into my mouth is - obviously absurd.

I am not sure that I quite understand Mr. Batten's criticism of my remark in reference to the retina, unless it is that differences in anatomical structure and physiological function in the same structure necessarily predisposes to a special vulnerability to specific organisms and toxins, a weakness with which I am quite familiar in regard to particular organs as a whole, but I am not aware that Mr. Batten has isolated any specific organism which attacks the macula as opposed to any other part, unless cerebral macular disease, comes into this category.

The brain shows variations in structure and function in its different parts, but the anatomist or neurologist could hardly be accused of ignorance for beginning a lecture with the statement that the interior of the skull is wholly occupied by the brain.

I am not an anthropologist but I can conceive of other methods of classification of the coloured races besides those mentioned by Mr. Batten, e.g., according to the formation of the skull, etc., but after all we are not concerned here in making black people white or white people yellow; but we are engaged in treating diseases of the eye for which purpose we need the combined efforts of the clinician (medical and surgical), the pathologist and the bacteriologist, and I think Mr. Batten must admit that the foundation of all successful treatment is pathology and bacteriology. Now, with regard to the really important part of $\mathrm{Mr}$. Batten's letter I do not question the two points he wishes to have conceded, nor that septic and cardio-vascular causes give rise to the ophthalmoscopic pictures which he has so ably illustrated, but they are not peculiar to the macula, and my contention is that diseases of the choroid should be studied separately from diseases of the retina in this situation as in any other part of the fundus, and, therefore, there is no justification for macular diseases being treated as a definite entity.

Yours faithfully,

Malcolm L. Hepburn.

London. December 6, 1924.

\section{NOTES}

THE George Henry Marshall Prize in OphthalPrize mology, of the University of Birmingham, has been awarded to Dr. T. Harrison Butler. This Prize in Ophthalmology, of the value of $£ 10$, is awarded or expended from time to time in the form of grants towards 